ADVANCES IN

PSYCHIATRY \& NEUROLOGY Postipy Psychiatrii Neurologi

\section{SELF-PERCEPTION OF ILLNESS AMONG PATIENTS WITH RELAPSING-REMITTING MULTIPLE SCLEROSIS (RRMS) - PRELIMINARY REPORT} PERCEPCJA WŁASNEJ CHOROBY
PRZEZ OSOBY Z RZUTOWO-REMISYJNĄ
POSTACIA STWARDNIENIA ROZSIANEGO
(SMRR) - DONIESIENIE WSTĘPNE

Correspondence to/

Adres do korespondencji:

Joanna Król

Instytut Psychologii

Wydział Humanistyczny

Uniwersytet Szczeciński

ul. Krakowska 69

71-017 Szczecin

tel./fax: +48914443240

e-mail: joanna.krol1@univ.szczecin.pl

Submitted/Otrzymano: 20.11.2016

Accepted/Przyjęto do druku: 20.12.2016

\author{
Joanna Król', Dorota Koziarska², Teresa Rzepa ${ }^{3}$, \\ Małgorzała Szcześniak', Przemysław Nowacki²
}

'Institute of Psychology, University of Szczecin, Poland

${ }^{2}$ Chair and Clinic of Neurology, Pomeranian Medical University in Szczecin, Poland ${ }^{3}$ SWPS University of Social Sciences and Humanities, Poznań Campus, Poland

'Instytut Psychologii, Uniwersytet Szczeciński, Szczecin, Polska

${ }^{2}$ Katedra i Klinika Neurologii, Pomorski Uniwersytet Medyczny, Szczecin, Polska
${ }^{3}$ SWPS Uniwersytet Humanistycznospołeczny, Wydział Zamiejscowy, Poznań, Polska

\begin{abstract}
Purpose: To determine the perception of illness among immunomodulatory treated patients with relapsing-remitting multiple sclerosis (RRMS) against demographic and socioeconomic factors and clinical data.

Methods: The following were used: Imagination and Perception of Illness Scale by Sak, 2013, original structured interview on demographic, socioeconomic and clinical data, disability status determined with the use of Expanded Disabilty Status Scale (EDSS).

Results: It was found that the patients consider MS to be a disease leading to physical sphere destruction. The fewest number of patients considered the disease to be a threat to others. Differences in perception of illness were observed in terms of sex of the respondents. Women tend to assign more destructive effect to the disease than men. The differences in perception were also found in relation to age, time from initiation of treatment and the level of disability.

Conclusions: Perception of illness is a highly individualised experience; therefore, the assessment of perception should be closely monitored and incorporated into the complex therapeutic treatment.
\end{abstract}

Key words: perception of illness, multiple sclerosis, psychological help, chronic disease, psychological therapy.

\title{
Streszczenie
}

Cel: Za cel pracy przyjęto ustalenie obrazu własnej choroby w ocenie leczonych immunomodulacyjnie pacjentów z rzutowo-remisyjną postacią stwardnienia rozsianego (SMRR), z uwzględnieniem czynników demograficznych, socjoekonomicznych i danych klinicznych.

Metody: W badaniu wykorzystano Skalę Wyobrażenia i Percepcji Choroby (Imagination and Perception of Illness Scale; Sak, 2013) oraz ustrukturyzowany autorski wywiad zbierający dane demograficzne, socjoekonomiczne i kliniczne, z uwzględnieniem stopnia niepełnosprawności (EDSS).

Wyniki: Ustalono, że badani pacjenci postrzegają SM przeważnie jako chorobę prowadzącą do destrukcji sfery fizycznej. Najrzadziej wskazywano na SM jako na czynnik powodujący zagrożenie dla innych ludzi. Zaobserwowano różnice międzypłciowe w percepcji choroby, które wskazują, że kobiety przypisują jej większą siłę destrukcyjną niż mężczyźni. Ponadto wykazano różnice w zakresie percepcji własnej choroby ze względu na wiek, okres, który upłynął od rozpoczęcia leczenia, oraz stopień niesprawności.

Wnioski: Doświadczanie choroby jest zindywidualizowanym odczuciem, dlatego też ocena percepcji choroby przez pacjenta powinna być stałym elementem opieki nad chorym, modyfikowanym na bieżąco w razie potrzeby, w kompleksowym postępowaniu terapeutycznym.

Słowa kluczowe: percepcja choroby, stwardnienie rozsiane, pomoc psychologiczna, choroba przewlekła. 
Self-perception of illness among patients with relapsing-remitting multiple sclerosis (RRMS) - preliminary report

Percepcja własnej choroby przez osoby z rzutowo-remisyjna postacia stwardnienia rozsianego (SMRR) - doniesienie wstępne

\section{INTRODUCTION}

Chronic disease is a critical life event understood as cognitively, emotionally, socially and existentially challenging situation, which requires the patient to develop new adaptive skills [1, 2]. In 1997, Rothwell et al. [3] demonstrated differences in the perception of illness by patients and doctors. Patients considered emotional and cognitive disorders and low vitality as the greatest limitations related to their condition. However, doctors paid particular attention to physical disability and the symptoms which can be easily classified as relating to the condition in view of the cases described in literature. It was concluded that the patients mainly focus on disease-related distress and the way it affects self-fulfilment, quality of life and, consequently, day-to-day functioning in the realm of family, professional and social life [4-6]. This shows the importance of improving knowledge about the patient's internal experience, particularly in terms of individualised perception of illness and its consequences [6]. Assigning meaning to the disease, which is an attempt to comprehend the new and difficult life situation, is a significant step in the adaptation process which, eventually, has a beneficial effect on the patient's emotional state, their ability to cope with stress as well as their behaviour and attitude towards treatment or following doctor's orders [7-9].

From the perspective of psychological stress and coping with chronic disease, the adaptation process is usually analysed with respect to its phase and specific nature, distinguishing the following phases of the process: stressor assessment, selection of adequate and effective reaction modes, re-evaluation of the situation and effectiveness of the actions taken [10]. Also, a particular attention is paid to the modes of perception and comprehending the situation of a chronic disease, including the content of cognitive structures (cognitive representation of illness) which consists of basic knowledge of the illness, its causes, course, consequences and likelihood of recovery $[11,12]$.

The issue under analysis is of particular importance from the stance of clinical and health psychology as well as in terms of cooperation between interdisciplinary medical team and the patients. Each patient develops an individual, cognitive construct of the disease which reflects personal (individual) life event [13]. Although the symptoms experienced by people suffering from a particular disease may be similar, yet the evaluation, configuration, intensity and effect on day-to-day functioning of such symptoms vary among patients. Apart from individual characteristics, i.e. personality traits, personal experience and expectations or other factors, such as relationship with medical personnel, family and other patients, may also affect the perception of the symptoms [11].

\section{WPROWADZENIE}

Choroba przewlekła to krytyczne wydarzenie życiowe rozumiane jako sytuacja trudna poznawczo, emocjonalnie, społecznie i egzystencjalnie, $\mathrm{z}$ tego powodu wymagająca nowych umiejętności przystosowawczych [1, 2]. W $1997 \mathrm{r}$. Rothwell i wsp. [3] wykazali różnice pomiędzy percepcją choroby z perspektywy pacjentów i lekarzy. Pacjenci wskazywali na zaburzenia emocjonalne i poznawcze oraz na spadek witalności jako największe ograniczenia związane $\mathrm{z}$ chorobą. Natomiast lekarze zwracali szczególną uwagę na niesprawność fizyczną oraz te objawy, które można „zaszufladkować" i odnieść do opisów choroby doprecyzowanych $\mathrm{w}$ literaturze naukowej. Podążając tropem dostrzeżonych różnic, ustalono, że pacjenci skupiają się głównie na uciążliwościach związanych $\mathrm{z}$ chorobą i na ich modyfikującym wpływie na samorealizację i jakość życia, a tym samym na codzienne funkcjonowanie $w$ rodzinie, środowisku zawodowym i społecznym [4-6]. To dowodzi, jak ważna jest wiedza na temat doświadczenia wewnętrznego osób chorych, zwłaszcza w zakresie zindywidualizowanej percepcji własnej choroby i wynikających stąd konsekwencji [6]. Nadawanie znaczenia własnej chorobie, czyli próba zrozumienia nowej i trudnej sytuacji życiowej, to bardzo ważny krok w procesie adaptacji do choroby, który pozytywnie wpływa na stan emocjonalny, sposób radzenia sobie ze stresem i zachowanie pacjenta oraz na jego postawę wobec leczenia, a zwłaszcza na stosowanie się do zaleceń lekarza [7-9].

W koncepcjach stresu psychologicznego i radzenia sobie $\mathrm{z}$ sytuacją choroby przewlekłej proces adaptacji analizuje się zazwyczaj w odwołaniu do jej fazowego, specyficznego charakteru, wyróżniając w przebiegu procesu następujące fazy: ocena stresora, wybór odpowiednich i skutecznych sposobów reagowania, powtórna ocena sytuacji i efektywności podjętego działania [10]. Przy tym kładzie się nacisk na sposoby percepcji i rozumienia sytuacji choroby przewlekłej, z uwzględnieniem treściowej zawartości struktur poznawczych (poznawcza reprezentacja choroby), na którą składa się podstawowa wiedza o istocie choroby, jej przyczynach, przebiegu, konsekwencjach i prawdopodobieństwie wyleczenia [11, 12].

Analizowany problem wydaje się szczególnie istotny z punktu widzenia psychologii klinicznej i psychologii zdrowia, a co za tym idzie - współpracy interdyscyplinarnego personelu medycznego z osobami chorymi. Wszak każdy pacjent konstruuje indywidualny, sobie właściwy, poznawczy obraz choroby, który stanowi odzwierciedlenie jego (i tylko jego) aktualnej sytuacji życiowej [13]. Mimo że u każdej osoby zmagającej się z tą samą chorobą mogą występować podobne objawy, to ich ocena, konfiguracja, natężenie i wpływ na codzienne funkcjonowanie są doświadczane odmiennie. Ponadto na ich odbiór i percepcję - oprócz cech osobowości, jednostkowych doświadczeń i oczekiwań - wpływają relacje z personelem medycznym, rodziną i innymi pacjentami [11]. 
Multiple sclerosis (sclerosis multiplex; MS) is a chronic, progressive and incurable disease of the central nervous system of inflammatory and neuro-degenerative character. Generally, the illness affects young adults between 20 and 40 years of age, mostly women [14]. Therefore, the diagnosis of the disease coincides with the most important life events, such as completing education, beginning and pursuit of career or starting a family. The diagnosis of an incurable and progressive chronic disease constitutes an extremely negative life event for a young patient; especially that the disease occurs unexpectedly in a form of reduced mobility, disturbed coordination and altered sensation. Non-motor manifestations of MS are chronic fatigue, mood and cognitive disorders [15-20], which are independent of the level of motor disability and can develop from the initial stage of the disease. The model course of MS is the initial stage with relapsing-remitting type of MS (RRMS) followed by progressive and increasing disability and the subsequent primary progressive stage (PPMS). The RRMS type of the disease is characterised by exacerbations of symptoms followed by remission. From the pathophysiological perspective, the manifestations of relapse are of inflammatory nature and require immunomodulatory treatment [21].

The prevalence of the RRMS type of the disease is three times higher in women, and the PPMS type occurs with comparable frequency in both men and women. Such a significant differentiation in term of sex and prevalence is characteristic for numerous autoimmune diseases, and the predisposing factor has not been identified yet $[18,22,23]$.

Multiple sclerosis is an incurable disease of unknown aetiology, characterised by variable and individual clinical course. As such, the disease requires from the patients and people close to them to develop adaptive skills. Doctors are required to have individual approach to such patients in order to understand their emotional reactions and behaviour. The analysis of variable perceptions of the disease allows to identify its underlying elements (often fragmentary and incorrect) and the possible relationship with the process of adaptation to illness. This analysis is particularly valuable in terms of determining and planning therapeutic interventions on different stages of the MS course.

\section{AIM}

The aim of the present paper is to determine the self-perception of illness among immunomodulatory treated patients with RRMS. The selection of the study group was based on the possibility of determining the perception of illness in the early stage of MS with the prospect of ongoing treatment. The analysis of perception of the illness takes into consideration the following:
Stwardnienie rozsiane (sclerosis multiplex - SM) jest przewlekłą, postępującą i nieuleczalną chorobą ośrodkowego układu nerwowego o charakterze zapalno-neurodegeneracyjnym. Choroba dotyka przeważnie młodych dorosłych, między 20.-40. rokiem życia, częściej kobiety niż mężczyzn [14]. Pojawia się zatem wraz z najważniejszymi wydarzeniami życiowymi, takimi jak zakończenie edukacji, początek i rozwój kariery zawodowej czy zakładanie rodziny. Tak więc wiadomość o nieuleczalnej i postępującej chorobie przewlekłej stanowi wyjątkowo negatywne przeżycie, z którym młody człowiek musi się uporać. Tym bardziej, że choroba pojawia się nieoczekiwanie, w formie zaburzeń ogólnej sprawności ruchowej, w tym również jej koordynacji, oraz jako zaburzenia czucia. Pozaruchowym elementem choroby jest przewlekłe zmęczenie wraz z zaburzeniami nastroju i przebiegu funkcji poznawczych [15-20]. Objawy pozaruchowe występują niezależnie od stopnia niesprawności ruchowej i mogą się rozwijać od najwcześniejszych etapów choroby. Modelowy przebieg SM to wstępna faza $\mathrm{z}$ postacią rzutowo-remisyjną (SMRR), w której po pewnym okresie dochodzi do postępującego narastania niesprawności i przejścia w fazę wtórnie postępującą (SMSP). Postać SMRR charakteryzuje się występowaniem zaostrzeń $\mathrm{z}$ następową poprawą. Z patofizjologicznego punktu widzenia objawy choroby związane z rzutami mają charakter stanu zapalnego i poddają się leczeniu immunomodulującemu [21].

Postać SMRR występuje nawet do 3 razy częściej u kobiet niż u mężczyzn, w przeciwieństwie do postaci pierwotnie postępującej, która u obu płci pojawia się w sposób zrównoważony. Tak znaczące zróżnicowanie płciowe jest charakterystyczne dla wielu chorób autoimmunologicznych, choć do dziś czynnik predysponujący kobiety pozostaje nieznany $[18,22,23]$.

Stwardnienie jako choroba nieuleczalna o nieznanej etiologii oraz zmiennym i indywidualnym przebiegu klinicznym wymaga działań przystosowawczych ze strony pacjenta i jego najbliższego otoczenia. Od lekarza natomiast wymaga indywidualnego podejścia ukierunkowanego na zrozumienie reakcji emocjonalnych i zachowań chorego człowieka. Analiza dynamicznie modyfikowanego obrazu choroby pomaga stwierdzić, jakie (często fragmentaryczne i nieprawdziwe) informacje się w nim znajdują oraz czy może mieć to związek z procesem adaptacji do choroby. Tego typu analiza jest szczególnie istotna dla rozpoznania i planowania trafnych oddziaływań pomocowych na różnych etapach przebiegu SM.

\section{CEL}

Celem pracy było ustalenie obrazu własnej choroby w ocenie leczonych immunomodulacyjnie pacjentów z SMRR. Wybór badanej grupy był podyktowany możliwością określenia obrazu własnej choroby w jej wczesnej fazie, z perspektywą aktywnego udziału w dalszym leczeniu. Analizie 
Self-perception of illness among patients with relapsing-remitting multiple sclerosis (RRMS) - preliminary report

Percepcja własnej choroby przez osoby z rzutowo-remisyjna postacią stwardnienia rozsianego (SMRR) - doniesienie wstępne

demographic factors (sex, age, education, being in a relationship, having children), socioeconomic factors (employed/unemployed, having/not having legal disability status), clinical data (level of disability measured with Expanded Disabilty Status Scale [EDSS]), time from diagnosis, time in neurological treatment, severity of the disease (measured by the number or relapses in the previous year).

The following research questions were explored: (1) Is there a relationship between the sex, age, education, being in relationship and having children and self-perception of illness among the RRMS patients? (2) Is there a relationship between professional status and having legal disability status and self-perception of illness among the RRMS patients? (3) Is there a relationship between the disability level, time from diagnosis, duration of treatment and severity of MS and self-perception of illness among RRMS?

\section{METHODS}

The study group consisted of patients diagnosed with MS according to the McDonald's criteria 2005 [24], under care of the neurological outpatients clinic at the Autonomous Public Teaching Hospital No. 1 in Szczecin. The study was conducted from March to June 2016. Out of 80 patients with relapsing-remitting MS undergoing immunomodulatory treatment, 71 patients were included into the study group. The exclusion criteria for participating in the study were depressive disorders (Beck Depression Inventory - BDI, score of 12 or more points) and/or deterioration of cognitive function (Mini Mental State Examination, score of less than 26 points), and/ or level of disability (EDSS score $>4.5$ ). The assessment of clinical status was performed by a specialist neurologist supervising the treatment of the patients included in the study.

The study was approved by the Bioethical Committee of the Institute of Psychology at the University of Szcze$\operatorname{cin}(\mathrm{KB} \mathrm{1/2016).}$

The age of the patients was from 20 to 56 years $(M=37.32 ; S D=8.28)$. Women constituted $68 \%$ of the study group; men - 32\% (the ratio was $2: 1$ and results from the gender distribution among the MS patients). Almost half of the patients (48\%) completed tertiary education, $13 \%$ - vocational or primary education. $31 \%$ of the patients were employed as blue-collar workers, $37 \%$ were students or white-collar workers. $32 \%$ of the patients in the study group were unemployed. Most of them (82\%) were in a steady relationship and had children (66\%). Two patients lived alone. More than half of the patients (54\%) had disability score of less than 1.0 , $25 \%$ of the patients showed discreet neurological symptoms (up to 2.0 points). Almost half of the patients (48\%) had legal disability status with the mean time of diagnosis poddano percepcję SM w zależności od czynników demograficznych (płeć, wiek, wykształcenie, pozostawanie w związku, posiadanie potomstwa), socjoekonomicznych (aktywność zawodowa/brak aktywności, orzeczenie o niepełnosprawności/brak orzeczenia) oraz danych klinicznych [poziom niepełnosprawności mierzony rozszerzoną skalą niepełnosprawności ruchowej (Expanded Disability Status Scale - EDSS), czas od rozpoznania SM, czas pozostawania w leczeniu neurologicznym, nasilenie choroby mierzone liczbą rzutów w ostatnim roku].

Sformułowano następujące pytania badawcze: 1) czy istnieje związek między płcią, wiekiem, wykształceniem, pozostawaniem w związku i posiadaniem potomstwa a percepcją własnej choroby przez osoby z SMRR; 2) czy istnieje związek między statusem zawodowym i posiadaniem orzeczenia o niepełnosprawności a percepcją własnej choroby przez osoby z SMRR; 3) czy istnieje związek między poziomem niepełnosprawności; czasem, jaki upłynął od rozpoznania choroby, czasem trwania leczenia i nasileniem choroby a percepcją własnej choroby przez osoby z SMRR.

\section{METODY}

Badanie przeprowadzono od marca do czerwca 2016 r. Grupę badaną stanowili pacjenci z rozpoznaniem SM zgodnie z kryteriami McDonald 2005 [24], pozostający w ambulatoryjnej opiece neurologicznej SPSK1 w Szczecinie. Spośród 80 chorych z rzutowo-remisyjną postacią $\mathrm{SM}$, leczonych immunomodulująco, do badania zakwalifikowano 71 osób. Kryterium wykluczenia była obecność zaburzeń depresyjnych (Skala Depresji Becka, BDI; $\geq 12$ pkt) i/lub spadek funkcji poznawczych (Mini Mental State Examination; wynik $\leq 26$ ), i/lub poziom niesprawności (wynik na skali EDSS $>4,5$ ). Ocena stanu klinicznego została przeprowadzona przez specjalistę neurologa nadzorującego leczenie badanych pacjentów.

Badanie stanowi część szerszego projektu, na przeprowadzenie którego uzyskano zgodę Komisji Bioetycznej Instytutu Psychologii Uniwersytetu Szczecińskiego (KB 1/2016).

Wiek badanych mieścił się w przedziale od 20 do 56 lat $(M=37,32 ; S D=8,28)$. W badanej grupie było $68 \%$ kobiet i 32\% mężczyzn (stosunek 2 : 1, co wynika ze specyfiki rozkładu płci wśród osób chorujących na SM). Niemal połowa (48\%) osób miała wykształcenie wyższe, a $13 \%$ - zawodowe lub podstawowe. Pracę fizyczną wykonywało $31 \%$ chorych, a $37 \%$ studiowało lub pracowało umysłowo. Nie pracowało $32 \%$ chorych. Większość pacjentów $(82 \%)$ pozostawała w stałym związku i posiadała dzieci (66\%). Dwie osoby mieszkały samotnie. Niepełnosprawność do 1,0 pkt cechowała ponad połowę (54\%) badanych, 25\% miało dyskretne objawy neurologiczne (do 2,0 pkt). Prawie połowa (48\%) badanych posiadała orzeczenie o niepełnosprawności, przy średnim czasie 
of approximately 8 years, and the mean time in immunomodulatory treatment of approx. 2.5 year.

The study used the Imagination and Perception of Illness Scale by Sak, 2013, and the original structured interview on demographic, socioeconomic and clinical data. Additionally, the level of disability (EDSS) was taken into consideration.

The Imagination and Perception of Illness Scale [6] relates to the Semantic Differential for Health [25] and includes 32 contradictory statements referring to perception and general understanding of a disease. The statements are grouped into 6 categories: loss of motivation to carry out specific activities, mental sphere destruction, physical sphere destruction, pessimism, being a threat to others and loss of control over the illness. The reliability of the scale was very high, i.e. $\alpha=0.950$.

The EDSS is based on clinical examination of the central nervous system; it includes the assessment of walking distance and allows quantifying disability in terms of symptoms typical for MS on a scale from 0.0 to 10.0 points [26], i.e. the higher the score, the greater the disability.

The analysis of the statistical data was performed with the use of IBM SPSS Statistics 20 software.

\section{RESULTS}

It was demonstrated (Table 1) that the patients in the study group consider MS to be a disease leading to destruction of their physical sphere. Slightly less frequently, the disease was considered a cause of mental sphere destruction and loss of control over the illness. The patients identified the disease as a threat to others least frequently.

The analysis of the relationship between the perception of illness and demographic parameters shows differences according to sex, which are mostly statistically significant (Fig. I). Women assigned more destructive effect to the disease than men, particularly in terms of the following categories: loss of motivation $\left(M_{k}=3.203\right.$ vs. $M_{m}=$ 2.478; $p=0.044)$, mental sphere destruction $\left(M_{k}=3.711\right.$ vs. $\left.M_{m}=2.942 ; p=0.038\right)$, physical sphere destruction chorowania ok. 8 lat i przy średnim czasie nieprzerwanego leczenia immunomodulującego - ok. 2,5 roku.

W badaniu wykorzystano Skalę Wyobrażenia i Percepcji Choroby (Imagination and Perception of Illness Scale; Sak, 2013), a także ustrukturyzowany autorski wywiad zbierający dane demograficzne, socjoekonomiczne i kliniczne, z uwzględnieniem stopnia niepełnosprawności (EDSS).

Skala Wyobrażenia i Percepcji Choroby [6] nawiązuje do Dyferencjału Semantycznego dla Zdrowia [25]. Jest zbudowana z 32 przeciwstawnych określeń, które dotyczą percepcji i ogólnego pojmowania choroby. Poszczególne określenia są pogrupowane w 6 kategorii: utrata motywacji do ukierunkowanej aktywności, destrukcja sfery psychicznej, destrukcja sfery fizycznej, pesymizm, zagrożenia dla otoczenia, utrata kontroli nad chorobą. Rzetelność skali uzyskana w niniejszym badaniu jest bardzo wysoka i wynosi $\alpha=0,950$.

Skala EDSS opiera się na badaniu klinicznym ośrodkowego układu nerwowego $\mathrm{z}$ oceną dystansu chodu i umożliwia kwantyfikację objawów typowych dla SM na skali od 0,0 do 10,0 pkt [26]. Im wyższa punktacja, tym większe nasilenie niesprawności.

Analiza danych statystycznych została przeprowadzona za pomocą pakietu IBM SPSS Statistics 20.

\section{WYNIKI}

Wykazano (tab. 1), że badani pacjenci postrzegają SM przeważnie jako chorobę prowadzącą do destrukcji sfery fizycznej, nieco rzadziej jako przyczynę destrukcji sfery psychicznej oraz utraty kontroli nad chorobą. Najrzadziej wskazywano na SM jako na czynnik powodujący zagrożenie dla innych ludzi.

Na podstawie analizy związku między percepcją choroby a parametrami demograficznymi zaobserwowano przeważnie istotne statystycznie różnice międzypłciowe (ryc. I). Kobiety przypisały chorobie większą siłę destrukcyjną niż mężczyźni $\mathrm{w}$ zakresie następujących kategorii: utrata motywacji $\left(M_{k}=3,203\right.$ vs $M_{m}=2,478$; $p=0,044)$, destrukcja sfery psychicznej $\left(M_{k}=3,711\right.$ vs $\left.M_{m}=2,942 ; p=0,038\right)$, destrukcja sfery fizycznej

Table 1. Perception of illness among multiple sclerosis (MS) patients

Tabela 1. Percepcja choroby przez osoby chore na stwardnienie rozsiane (SM)

\begin{tabular}{|l|c|c|c|c|}
\hline & N & M & SD & $\begin{array}{c}\text { Standard error of the mean/ } \\
\text { Błąd standardowy średniej }\end{array}$ \\
\hline Physical sphere destruction/Destrukcja sfery fizycznej & 71 & 3.91 & 1.12 & 0.13419 \\
\hline Mental sphere destruction/Destrukcja sfery psychicznej & 71 & 3.46 & 1.32 & 0.15722 \\
\hline Loss of controls over the illness/Utrata kontroli nad choroba & 71 & 3.31 & 1.46 & 0.17333 \\
\hline Loss of motivation/Utrata motywacji & 71 & 2.96 & 1.27 & 0.15126 \\
\hline Pessimism/Pesymizm & 71 & 2.84 & 1.42 & 0.16898 \\
\hline Threat to others/Zagrożenie dla otoczenia & 71 & 0.95 & 1.31 & 0.15581 \\
\hline
\end{tabular}

$N$ - number of respondents, $M$ - mean, SD - standard deviation/N - liczba badanych, $M$-średnia, SD - odchylenie standardowe 


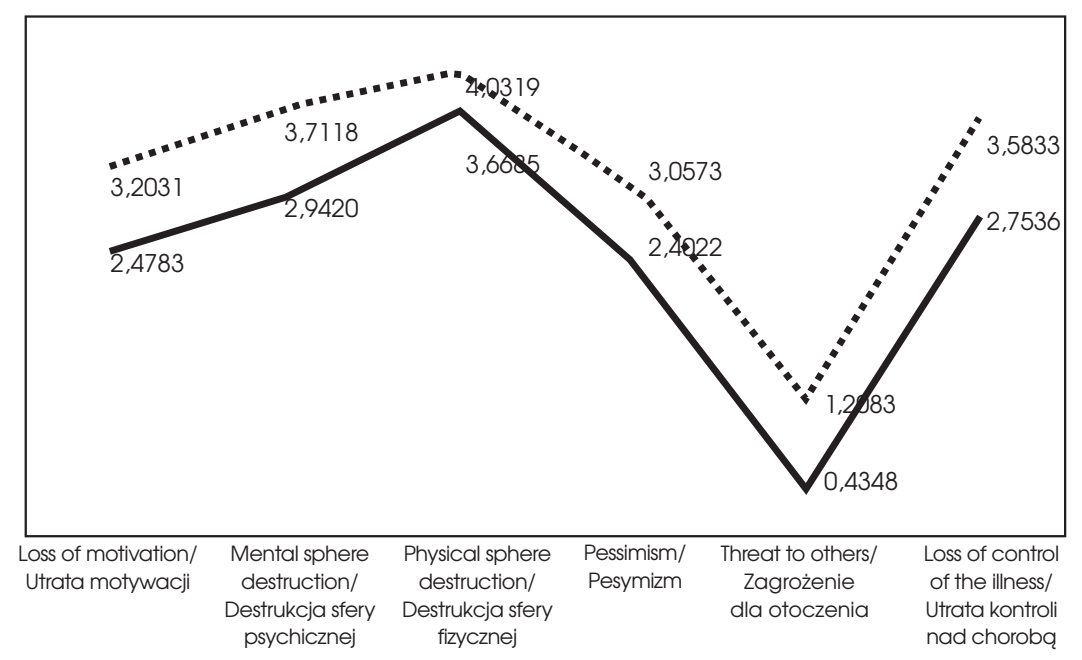

- Men/Mężczyźni

Figure I. Self-perception of illness by women and men with multiple sclerosis (MS)

Rycina I. Percepcja własnej choroby przez kobiety i mężczyzn ze stwardnieniem rozsianym (SM)

$\left(M_{k}=4.031\right.$ vs. $\left.M_{m}=3.665 ; p=0.206\right)$, pessimism $\left(M_{k}=3.057\right.$ vs. $\left.M_{m}=2.402 ; p=0.106\right)$, threat to others $\left(M_{k}=1.208\right.$ vs. $\left.M_{m}=0.434 ; p=0.003\right)$ and loss of control over the illness $\left(M_{k}=3.583\right.$ vs. $\left.M_{m}=2.753 ; p=0.024\right)$.

The analysis shows differences in terms of perception of illness according to age of the patients: patients over 37 years of age considered MS to be a substantial and statistically significant reason for pessimism $\left(M_{s}=3.20\right.$; $\left.M_{m}=2.53 ; p=0.041\right)$ and loss of control over the illness $\left(M_{s}=3.68 ; M_{m}=2.99 ; p=0.044\right)$ more often than younger patients.

No differences in terms of perception of illness were found depending on education, being in a relationship or having children. Similarly, no differences were found in terms of employment or legal disability status. Additional analyses (post hoc ANOVA) did not show any differences in perception of illness according to the time from diagnosis or the number of relapses in the previous year. Correlation statistics only shows the statistical tendency of the relationship between the time from initiation of treatment and pessimism $(r=-0.203 ; p=0.094)$. This means that with the increasing time of treatment, the disease is less frequently considered a cause of pessimism. Furthermore, it was demonstrated that patients with lower disability status are more likely to consider MS as a disease which poses a threat to others $(M=1.117 ; S D=1.390 ; M=0.309$; $S D=0.619 ; p=0.002)$.

\section{DISCUSSION}

The aim was to establish self-perception of illness among the RRMS patients in relation to the selected demograph-
$\left(M_{k}=4,031\right.$ vs $\left.M_{m}=3,665 ; p=0,206\right)$, pesymizm $\left(M_{k}=3,057\right.$ vs $\left.M_{m}=2,402 ; p=0,106\right)$, zagrożenie dla otoczenia $\left(M_{k}=1,208\right.$ vs $\left.M_{m}=0,434 ; p=0,003\right)$ i utrata kontroli nad chorobą $\left(M_{k}=3,583\right.$ vs $\left.M_{m}=2,753 ; p=0,024\right)$.

Wykazano także różnice w zakresie percepcji własnej choroby ze względu na wiek: osoby powyżej 37. roku życia postrzegały SM jako bardziej znaczący i statystycznie istotny powód pesymizmu $\left(M_{s}=3,20 ; M_{m}=2,53 ; p=0,041\right)$ oraz utraty kontroli nad chorobą niż osoby młodsze $\left(M_{s}=3,68 ; M_{m}=2,99 ; p=0,044\right)$.

Nie odnotowano różnic w zakresie percepcji własnej choroby w zależności od poziomu wykształcenia, pozostawania (bądź nie) w stałym związku i posiadania (bądź nie) dzieci. Podobnie nie wykazano różnic w tym zakresie ze względu na czynnik aktywności zawodowej i jej braku oraz posiadania i nieposiadania orzeczenia o niepełnosprawności. Dodatkowe analizy (post hoc ANOVA) nie wykazały różnic w zakresie percepcji choroby w powiązaniu z okresem chorowania oraz liczbą rzutów w ostatnim roku. Statystyki korelacyjne wskazały jedynie na tendencję statystyczną dotyczącą związku między liczbą lat od rozpoczęcia leczenia a pesymizmem $(r=-0,203$; $p=0,094)$. To oznacza, że im dłużej trwa leczenie, tym SM jest postrzegane jako coraz słabsza przyczyna pesymistycznych odczuć. Ponadto ustalono, że pacjenci z niższym stopniem niesprawności są skłonni postrzegać SM jako chorobę zagrażającą otoczeniu $(M=1,117$; $S D=$ $1,390 ; M=0,309 ; S D=0,619 ; p=0,002)$.

\section{DYSKUSJA}

Celem badania było ustalenie obrazu własnej choroby w percepcji osób z SMRR w kontekście wybranych zmiennych de- 
ic, socioeconomic and clinical variables. It was found that sex is a variable which modifies the perception of illness as in all analysed dimensions women considered the disease to be more severe in effect than men. The results indicate that women are more aware and take greater care of their health than men and are committed to adopting healthy lifestyle [27-29]. The results of the European Health Interview Survey (EHIS) [30] clearly show that women use medical services more frequently than men, as well as take medicine more frequently and take preventive measures. The results of the study of patients with other chronic diseases show a marked decrease in the quality of life in the adversely changed life situation $[2,31]$. However, the duration of illness, symptoms and severity of the disease markedly affects the assessment of life quality in women, and has no influence on the respective issue in men [32]. Previous studies also show that the perception of stigma related to a chronic disease is higher in women than in men [33]. The stigma of a chronic disease is manifested by despair, remorse and shame, greater emotional burden in social situations and expectations of rejection by others. However, in men the stigma was connected with the fear of losing one's job more often than in women [34, 35]. Moreover, literature on the subject states that prevalence of depression among women as compared to men is comparable to that of MS $-2: 1$. Such a disproportion in prevalence is usually explained with reference to medical factors as well as to the hypothesis that women admit to experiencing depressive states, feeling of threat and negative emotions connected with the course of the disease more often and more openly than men [36-39]. Perhaps for these reasons, it is women who are mostly active in Internet forums and websites run by the MS patients. The mentioned data suggest that the illness is experienced more severely by women than by men and, therefore, contributes to a decrease in the assessment of the quality of life.

The results of this study indicate that women are not only at a higher risk for the aforementioned disease-related problems but also identify sex as one of the basic elements which should be taken into account while organising therapeutic interventions for the MS patients.

It was found that the negative perception of the destructive nature of the disease increases with age, which leads to the feeling of loss of control over the disease and increased pessimism [40]. The feeling of loss of control connected with pessimistic attitude is one of the commonly observed characteristics of MS and results from the unpredictable and progressive character of the disease [41]. The obtained results are in line with the findings of other studies on self-perception of other illnesses which show that older patients demonstrate only a limited belief in the possibility of having control over the disease [42] or consider the disease to be a substantial cause of physical sphere destruction [6]. mograficznych, socjoekonomicznych i klinicznych. Stwierdzono, że płeć stanowi zmienną modyfikującą postrzeganie choroby, gdyż na wszystkich analizowanych dymensjach kobiety postrzegały ją jako bardziej dotkliwą niż mężczyźni. Zgodnie z wynikami badań kobiety są bardziej niż mężczyźni świadome stanu swojego zdrowia, bardziej o nie dbają i bardziej się angażują w prowadzenie zdrowego stylu życia [27-29]. Wyniki Europejskiego Ankietowego Badania Zdrowia (EHIS) [30] jednoznacznie pokazały, że kobiety częściej niż mężczyźni korzystały z usług medycznych, częściej niż oni zażywały leki i dbały o profilaktykę. Badania przeprowadzone wśród pacjentów $\mathrm{z}$ innymi przewlekłymi chorobami wskazują na znaczący spadek jakości życia $\mathrm{w}$ negatywnie zmienionej sytuacji życiowej $[2,31]$. Jednakże dłuższe chorowanie, przewlekłość objawów i odczuwana ciężkość choroby oddziałują wyraźniej na ocenę jakości życia przez kobiety, a nie wpływają na jakość życia w ocenie mężczyzn [32]. Dotychczasowe badania wskazują też na wyższe u kobiet niż u mężczyzn poczucie stygmatyzacji spowodowanej przewlekłą chorobą [33]. Przejawiało się ono $\mathrm{w}$ formie rozpaczy, poczucia winy i wstydu, większego obciążenia emocjonalnego w sytuacjach społecznych i oczekiwania na odrzucenie przez innych ludzi. Natomiast u mężczyzn przejawy poczucia stygmatyzacji wiązały się częściej niż u kobiet z obawą o utratę pracy [34,35]. Ponadto w literaturze podaje się, że przewaga kobiet nad mężczyznami w zachorowalności na depresję wynosi - podobnie jak w przypadku SM - 2: 1 . Tę dysproporcję wyjaśnia się przeważnie w odwołaniu do czynników medycznych, ale i do hipotezy, że kobiety częściej i bardziej otwarcie niż mężczyźni przyznają się do przeżywania stanów depresyjnych oraz doświadczania zagrożenia i negatywnych emocji związanych z przebiegiem choroby [36-39]. Prawdopodobnie dlatego to głównie kobiety udzielają się na forach i stronach internetowych zrzeszających osoby chorujące na SM. Przytoczone dane sugerują, że choroba ma dla kobiet większe i bardziej dotkliwe znaczenie niż dla mężczyzn, a tym samym znacząco przyczynia się do obniżenia oceny jakości życia.

Przeprowadzone badanie nie tylko wskazuje na kobiety jako na bardziej narażone na zagrożenia towarzyszące SM, lecz także wyróżnia czynnik płci jako jeden z podstawowych elementów, który powinien być uwzględniany przy organizowaniu oddziaływań pomocowych ukierunkowanych na chorych z SM.

Ustalono, że wraz z wiekiem wzrasta percepcja destrukcyjnego charakteru SM oraz że ten negatywny wpływ prowadzi do utraty kontroli nad chorobą i spotęgowania pesymizmu [40]. Przekonanie o możliwości utraty kontroli nad chorobą, powiązane z pesymistycznym nastawieniem, jest zgodne ze specyfiką SM, z jej nieprzewidywalnością i postępującym charakterem [41]. Uzyskany wynik jest zbliżony do rezultatów badań na temat percepcji innych chorób, na podstawie których stwierdzono, iż starsi pacjenci najczęściej przejawiają słabe przekonanie o możliwości kontroli własnej choroby [42] bądź postrzegają ją jako istotną przyczynę destrukcji sfery fizycznej [6]. 
Self-perception of illness among patients with relapsing-remitting multiple sclerosis (RRMS) - preliminary report

Percepcja własnej choroby przez osoby z rzutowo-remisyjna postacia stwardnienia rozsianego (SMRR) - doniesienie wstępne

No differences in terms of perception of illness were found in relation to education, being in a relationship and having children - the fact which confirms the results of another study [6]. Furthermore, there were no differences depending on being in employment or having legal disability status. These findings are in contrast with the results obtained by Sak [6], who demonstrated that professionally active patients consider the disease to be less detrimental to the physical sphere. However, the results of yet another study [43] suggest that being in employment is not necessarily beneficial to health. Nowadays, due to changing labour market status, professionally active people may suffer greater stress, which negatively affects their mood and well-being.

The analysis of perception of MS in relation to clinical variables shows correlation with the time in treatment and with the level of disability. Similar results were obtained by Rachel Vaughan [41], who additionally demonstrated lack of correlation between perception of MS and the time from diagnosis. The results of own research show a statistical tendency $(r=-0.203 ; p=0.094)$, which implies that the longer the patients remain in treatment, the less likely they are to consider the disease as the cause of pessimism. It may be assumed that the perspective of being in treatment results in an increased feeling of control over the disease. It is noteworthy that only since 2014, the MS patients in Poland are offered first-line neurological treatment without a time limit. Previously, the therapeutic programme offered to the MS patients was to be terminated after a few years, regardless of its outcome.

The results on perception of MS by patients with a minimal level of disability were slightly surprising. Such patients demonstrated a conviction that the disease is a threat to others understood as deterioration of the ability to function in family or work environment. Anxiety experienced by the MS patients stems from fear of disease progression, job loss, being increasingly dependent on others, risk of breaking family and social ties or being rejected [44]. With limited disability, the new experience of having a disease may correspond to fear of gradually becoming a burden to others. However, in the adaption and coping processes, as long as the patients fulfil their commitments to the family, the perception of illness as a threat to others may not be so strong [45]. Studies show that with increasing the disability level, the patients are care-dependent and half of the married patients consider MS to have a negative effect on fulfilling their family role and they point to a corresponding impairment of family relationship [46]. Moreover, in the case of chronic, progressive diseases it is known in advance that the patient's condition may deteriorate. The patient may then develop the style of functioning which consists in intentionally concealing the symptoms of the disease $[47,48]$. Initially, the stigma of MS is generally inconspicuous to
Wśród badanych z SM nie odnotowano różnic w zakresie percepcji własnej choroby w zależności od poziomu wykształcenia, pozostawania w stałym związku i posiadania dzieci, co potwierdza wyniki innego badania [6]. Nie odnotowano także różnic $\mathrm{w}$ tym zakresie pomiędzy osobami pracującymi i niepracującymi oraz posiadającymi bądź nieposiadającymi orzeczeń o niepełnosprawności. Te wyniki różnią się od uzyskanych przez Saka [6], który ustalił, że pacjenci aktywni zawodowo postrzegali własną chorobę jako mniej destrukcyjną dla ich sfery fizycznej. Jednak rezultaty innego badania sugerują [43], że nie zawsze aktywność zawodowa jest lepsza dla zdrowia. W kontekście niepewności związanej z rynkiem pracy, osoby aktywne zawodowo mogą przeżywać stres przed utratą zatrudnienia, co wpływa negatywnie na ich nastrój i samopoczucie [35].

Analiza percepcji SM w relacji do zmiennych klinicznych ujawniła związek $\mathrm{z}$ okresem pozostawania $\mathrm{w}$ leczeniu oraz ze stopniem niepełnosprawności. Podobne wyniki uzyskała Rachel Vaughan [41], która ponadto odnotowała brak związku między percepcją SM a czasem, który upłynął od rozpoznania choroby. W przeprowadzonym badaniu własnym stwierdzono tu występowanie tendencji statystycznej $(r=-0,203 ; p=0,094)$, która oznacza, że im osoby z SM dłużej są leczone, tym rzadziej traktują chorobę jako przyczynę odczuwania pesymizmu. Można przypuszczać, że perspektywa pozostawania $\mathrm{w}$ systematycznym leczeniu wywołuje u pacjentów poczucie sprawowania kontroli nad chorobą [40]. W tym miejscu warto zaznaczyć, że w Polsce dopiero od 2014 r. pacjenci z SM objęci leczeniem neurologicznym mają dostęp do programu terapeutycznego I linii bez ograniczeń czasowych. Poprzednio zakładano przerwanie terapii po kilku latach, bez względu na jej efektywność.

Nieco zaskakująca okazała się percepcja SM przez osoby z niewielkim stopniem niepełnosprawności, które wskazały na własną chorobę jako zagrażającą otoczeniu w sensie pogorszenia jakości funkcjonowania w środowisku rodzinnym czy zawodowym. Lęk i niepokój doświadczany przez chorych na SM wynika raczej z obawy o postęp choroby, utratę pracy, rosnącą zależność od opiekunów, groźbę zerwania więzi czy odrzucenia z grona rodzinnego bądź społecznego [44]. Przy jeszcze niewielkiej niesprawności świadomość nowego doświadczenia chorowania może wiązać się z obawą o stopniowe stawanie się ciężarem dla innych. Jednakże w procesie adaptacji i radzenia sobie, kiedy osoba chora wypełnia zobowiązania wobec bliskich, percepcja choroby jako zagrożenia dla innych może nie być już tak silna [45]. Badania pokazują, że wraz z utratą sprawności chorzy wymagają systematycznej opieki oraz że połowa chorych pozostających $\mathrm{w}$ związkach małżeńskich uznaje niekorzystny wpływ SM na wypełnianie ról rodzinnych i dostrzega pogorszenie relacji z członkami rodziny [46]. Ponadto $\mathrm{w}$ przypadku chorób o postępującym i przewlekłym charakterze, gdy z góry wiadomo, że trzeba być przygotowanym na spotęgowanie oznak stygmatyzujących chorego, pojawić się może styl funkcjonowania polegają- 
a casual observer. However, the patient is aware that it is up to them if the diagnosis is to be made public or concealed. This is a difficult decision as the patient is aware of the consequences resulting from revealing the diagnosis and the possibility of being stigmatised, particularly given that the prognosis is uncertain and the course of the disease is unpredictable [49]. In the case of patients with a low level of disability, the disease may foster the feelings of uncertainty and fear of being dependent on others in terms of fulfilling their social and professional roles.

The results discussed here constitute a preliminary report as a relatively new tool was used in the analysis, which does not allow application of comparative analysis with the results of previous studies. The value of the research (and, at the same time, its limitation) is a relatively small and homogenous number of SM patients. In the subsequent studies, it could be worthwhile to enlarge the study group and compare the obtained results with patients suffering from other chronic diseases. Also, it would seem valid to expand the analysis in order to investigate the relationship between the perception of illness and acceptance levels with personality factors, such as personal resources or temperamental features.

Several practical implications of great importance follow from the presented study. Perception of illness is highly individualised and understanding the underlying factors may help in providing assistance to the MS patients. Negative perception of illness coincides with lower self-esteem, depression and even mental fatigue and exhaustion [50-52]. In accordance with the biopsychosocial approach, the task of the treatment team is to earn the trust of patients for the purpose of motivating them to share their thoughts and opinions [6], which in turn facilitates implementation of recommendations, improves the effects of therapeutic and psychoeducational interventions [53].

In conclusion, the following should be emphasised:

1. The identified differences in terms of perception of MS confirm that experiencing the disease is a highly individualised life situation.

2. The assessment of perception of illness should be incorporated into a complex therapeutic treatment and modified if need be.

3. The obtained results improve knowledge on self-perception of the illness. cy na intencjonalnym ukrywaniu objawów choroby [47, 48]. Najpierw stygmat SM jest $\mathrm{z}$ reguły niewidoczny dla postronnego obserwatora. Jednakże chory wie, że to od niego zależy decyzja o ujawnieniu czy zatajeniu informacji o diagnozie. Decyzja ta jest niezwykle trudna, gdyż osoba chora jest świadoma konsekwencji związanych z możliwością naznaczenia jej przez otoczenie i to tym bardziej, że rokowanie jest trudne do przewidzenia i niepewne [49]. Dla osób z niskim stopniem niepełnosprawności SM może zatem oznaczać wciąż niejasną i naznaczoną wieloma obawami perspektywę, wzbudzającą poczucie zagrożenia co do możliwości pozostawania kimś niezależnym od otoczenia oraz efektywnie wypełniającym role zawodowe i społeczne.

Prezentowane wyniki mają charakter wstępnego doniesienia, ponieważ zastosowano stosunkowo nowe narzędzie, co uniemożliwia ich porównanie z rezultatami wcześniejszych badań. Wartością (a jednocześnie ograniczeniem) przeprowadzonego badania jest niewielka i jednorodna grupa złożona z chorych na SM. W kolejnych badaniach warto byłoby zwiększyć jej liczebność oraz porównać wyniki uzyskane przez chorych z różnymi postaciami SM i z różnym stopniem niesprawności oraz z wynikami pacjentów dotkniętych innymi chorobami przewlekłymi. Równie istotne wydaje się poszerzenie analiz o związek percepcji choroby z poziomem jej akceptacji i z takimi czynnikami osobowościowymi, jak zasoby osobiste czy cechy temperamentalne.

Z przeprowadzonego badania wynika kilka ważnych implikacji praktycznych. Percepcja własnej choroby jest zindywidualizowana i dlatego dotarcie do niej może pomóc w zrozumieniu problemów pacjentów zmagających się z SM. Negatywne przekonania na temat własnej choroby współwystępują z niższą samooceną, depresją, a nawet psychicznym zmęczeniem i wyczerpaniem [50-52]. Zgodnie z podejściem biopsychospołecznym, zadaniem zespołu leczącego powinno być zdobywanie zaufania osób chorych, głównie w celu ich motywowania do dzielenia się swymi spostrzeżeniami i opiniami [6], co uskutecznia wdrażanie odpowiednich zaleceń oraz oddziaływań terapeutycznych i psychoedukacyjnych [53].

W podsumowaniu należy stwierdzić, że:

1. Zidentyfikowane odmienności $\mathrm{w}$ zakresie percepcji SM potwierdzają tezę, że doświadczanie choroby jest unikalnym, zindywidualizowanym odczuciem.

2. Ocena percepcji choroby przez pacjenta powinna być stałym elementem opieki nad chorym, modyfikowanym na bieżąco w razie potrzeby, w kompleksowym postępowaniu terapeutycznym.

3. Uzyskane wyniki poszerzają zakres wiedzy dotyczącej percepcji własnej choroby. 
Self-perception of illness among patients with relapsing-remitting multiple sclerosis (RRMS) - preliminary report

Percepcja własnej choroby przez osoby z rzutowo-remisyjna postacią stwardnienia rozsianego (SMRR) - doniesienie wstępne

Conflict of interest/Konflikt interesu

Absent./Nie występuje.

Financial support/Finansowanie

Absent./Nie występuje.

\section{References/Piśmiennicłwo}

1. Lazarus RS, Folkman S. Stress, appraisal and coping. New York: Springer; 1984.

2. Heszen I, Sęk H. Psychologia zdrowia [Health Psychology]. Wydawnictwo Naukowe PWN, Warszawa 2007.

3. Rothwell PM, McDowell Z, Wong CK, Dorman PJ. Doctors and patients don't agree: cross sectional study of patients' and doctors' perceptions and assessments of disability in multiple sclerosis. BMJ 1997; 314: $1580-1583$.

4. Diefenbach MA, Leventhal $\mathrm{H}$. The common sense model of illness representation theoretical and practical considerations. J Soc Distr Hom 1996; 5: 11-38.

5. Toombs SK. The Meaning of Illness. A Phenomenological Account of the Different Perspectives of Physician and Patient. Dordrecht: Kluwer Academic Publishers; 2003.

6. Sak J. Wielowymiarowość postrzegania choroby w kontekście przekonań zdrowotnych i poczucia sensu życia: rozprawa habilitacyjna [Multidimensional perception of illness in the context of individual health beliefs and the sense of meaning of life: post-doctoral dissertation]. Lublin: Uniwersytet Medyczny w Lublinie; 2013.

7. Leventhal H, Idler EL, Leventhal EA. The impact of chronic illness on the self-system. W: Cotrada RJ, Ashmore RD (eds.). Self, social identity and physical health: Interdisciplinary explorations. New York: Oxford University Press; 1999, p. 185.

8. Watkins KW, Connell CM, Fitzgerald JT, Klem L, Hickey T, Ingersoll-Dayton B. Effects of adults' self regulation on quality of life outcomes. Diabetes Care 2000; 23: 1511-1515.

9. Steuden S. Z psychologicznej problematyki zdrowia i choroby [Psychological health issues]. W: Oleś P, Steuden S, Toczydłowski J (eds.). Jak świata mniej widzę. Zaburzenia widzenia a jakość życia [How I see less of the world. Visual impairment and the quality of life]. Lublin: Towarzystwo Naukowe KUL; 2002, p. 27.

10. Leventhal H, Halm E, Horowitz C, Leventhal E, Ozakinci G. Living with chronic illness: A contextualized, self-regulation approach. W: Sutton S, Baum A, Johnston M (eds.). The Sage handbook of health psychology. London: Sage Publication; 2005, p. 197-240.

11. Leventhal H, Meyer D, Nerenz D. The commonsense representation of illness danger. W: Rachman S (ed.). Medical Psychology. New York: Pergamon; 1980, p. 7-30.

12. Ziarko M. Zmaganie się ze stresem choroby przewlekłej [Coping with stress of chronic illness]. Poznań: Wydawnictwo Naukowe Wydziału Nauk Społecznych UAM; 2014.

13. Adamska M, Juczyńska K, Miniszewska J. Sposób postrzegania własnej choroby jako czynnik wyznaczający jej akceptację u osób chorych na łuszczycę [Perception of the disease as determinant of illness acceptance in patients with psoriasis]. Curr Probl Psychiatry 2015; 16: 26-31.

14. Runmarker B, Anderson O. Prognostic factors in a multiple sclerosis incidence cohort with twenty-five years of follow-up. Brain 1993; 116: 114-134.

15. Szepietowska EM. Zaburzenia w funkcjonowaniu poznawczym chorych na stwardnienie rozsiane [Disorders in cognitive functioning of patients with multiple sclerosis]. W: Herzyk A, Kądzielawa D (eds.). Związek mózg - zachowanie w ujęciu neuropsychologii klinicznej [Relation brain - behavior in clinical neuropsychology]. Lublin: Wydawnictwo Uniwersytetu Marii Skłodowskiej-Curie; 1997, p. 217-246.

16. Szepietowska EM. Procesy pamięciowe u osób chorych na stwardnienie rozsiane - analiza neuropsychologiczna [Memory processes in patients with multiple sclerosis - neuropsychological analysis]. Lublin: Wydawnictwo Uniwersytetu Marii Skłodowskiej-Curie; 2006.

17. Szepietowska EM. Pomoc psychologiczna dla chorych na stwardnienie rozsiane [Psychological help for patients with multiple sclerosis]. W: Potemkowski A (ed.). Psychologiczne aspekty stwardnienia rozsianego [Psychological aspects of multiple sclerosis]. Poznań: Termedia Wydawnictwo Medyczne; 2010, p. 133-146.

18. Selmaj K. Stwardnienie rozsiane - kryteria diagnostyczne i naturalny przebieg choroby [Multiple sclerosis - diagnostic criteria and natural course of the disease]. Polski Przegląd Neurologiczny 2005; 1: 99-105.

19. Palasik W. Zespół zmęczeniowy, depresja i zaburzenia funkcji poznawczych - podstawowe czynniki zmieniające jakość życia chorych ze stwardnieniem rozsianym [Fatigue syndrome, depression and cognitive dysfunction basic factors changing quality of life of patients with multiple sclerosis]. Aktualności Neurologiczne 2009; 9: 267-271.

20. Rzeszutko E. Objawy lęku i depresji u pacjentów z przebiegiem rzutowo-remisyjnym stwardnienia rozsianego [Symptoms of anxiety and depression in patients with relapsing-remitting multiple sclerosis]. Curr Prob Psychiatry 2013; 14: 216-221.

21. Kappos L, Kuhle J, Multanen J, Kremenchutzky M, Verdyn di Cantogno E, Cornelisse P, et al. Factors influencing long-term outcomes in relapsing-remitting multiple sclerosis: PRISMS-15. J Neurol Neurosurg Psychiatry 2014; 86: 1202-1207. 
22. Lublin FD, Reingold SC. Defining the clinical course of multiple sclerosis: results of an international survey. National Multiple Sclerosis Society (USA) Advisory Committee on Clinical Trials of New Agents in Multiple Sclerosis. Neurology 1996; 46: 907-911.

23. Potemkowski A. Epidemiologia. W: Losy J (ed.). Stwardnienie rozsiane [Multiple sclerosis]. Lublin: Wydawnictwo Czelej; 2013, p. 1-16.

24. Polman CH, Reingold SC, Edan G, Filippi M, Hartung HP, Kappos L, et al. Diagnostic criteria for multiple sclerosis: 2005 revisions to the "McDonald Criteria". Ann Neurol 2005; 58: 840-846.

25. Jenkins DC. The Semantic Differential for Health. A Technique for measuring. Beliefs about disease. Public Health Rep 1966; 81: 549-558.

26. Kurtzke JF. Rating neurologic impairment in multiple sclerosis: an expanded disability status scale (EDSS). Neurology 1983; 33: 1444-1452.

27. Renzetti CM, Curran DJ. Kobiety, mężczyźni i społeczeństwo [Women, men and society]. Warszawa: Wydawnictwo Naukowe PWN; 2005.

28. Grogan S. Body image: Understanding body dissatisfaction in men, women, and children. London, New York: Routledge; 2008.

29. De Walden-Gałuszko K. Jakość życia - rozważania ogólne [Quality of life - general considerations]. W: De Walden-Gałuszko K, Majkowicz M (eds.). Jakość życia w chorobie nowotworowej [Quality of life in cancer disease]. Gdańsk: Wydawnictwo Uniwersytetu Gdańskiego; 1994, p. 13-22.

30. Zdrowie i zachowanie zdrowotne mieszkańców Polski w świetle Europejskiego Ankietowego Badania Zdrowia (EHIS) 2014 [Health and Health Behavior of Polish Residents in the Light of the European Health Survey (EHIS) 2014]. Warszawa: Główny Urząd Statystyczny; 2015.

31. Chojnacka-Szawłowska G. Psychologiczne aspekty przewlekłych chorób somatycznych [Psychological aspects of chronic somatic diseases]. Warszawa: Vizja Press; 2012.

32. Holm EA, Esmann S, Jemec GBE. Does visible atopic dermatitis affect quality of life more in women than in men? Gend Med 2004; 1: 125-130.

33. Schmid-Ott G, Jaeger B, Kuensbeck HW, Ott R, Lamprecht F. Dimensions of stigmatization in patients with psoriasis in a "Questionnaire on Experience with Skin Complaints". Dermatology 1996; 193: 304-310.

34. Gupta MA, Gupta AK. Age and gender differences in the impact of psoriasis on quality of life. Int J Dermatol 1995; 34: 700-703.

35. Böhm D, Stock Gissendanner S, Bangemann K, Snitjer I, Werfel T, Weyergraf A, et al. Perceived relationships between severity of psoriasis symptoms, gender, stigmatization and quality of life. J Eur Acad Dermatol Venereol 2013; 23: 220-226.

36. Seligman MEP, Walker EF, Rosenhan DL. Zaburzenia nastroju. Psychopatologia [Psychopathology]. Poznań: Wydawnictwo Zysk i S-ka; 2003, p. 268-323.

37. Kossakowska M. Strategie radzenia sobie $\mathrm{z}$ chorobą przewlekłą w stwardnieniu rozsianym [Strategies of coping with chronic illness in patients with multiple sclerosis]. Post Psychiatr Neurol 2008; 17: 15-21.

38. Leksowska A, Jaworska I, Gorczyca P. Choroba somatyczna jako wyzwanie adaptacyjne dla człowieka [Somatic illness as an adaptive challenge for men]. Folia Cardiologica Excerpta 2011; 6: 244-248.

39. Lenkiewicz M, Silczak A, Szymańska A, Żyłkowska M. Reprezentacja własnej choroby i poczucie koherencji jako predykatory zdrowia u osób z SM [Self-perception of the disease and sense of coherence as health predictors in group of patients with MS]. Pielęgniarstwo Polskie 2011; 3: 175-180.

40. Williams J, Koocher GP. Adressing loss of control in chronic illness: Theory and practice. Psychotherapy 1998; 35: 325-335.

41. Vaughan R. The illness representations of multiple sclerosis and their relations to outcome. A thesis submitted to the Faculty of Medicine of the University of Leicester for the degree of Doctor of Clinical Psychology, 1999. Available from: https://lra.le.ac.uk/bitstream/2381/31282/1/U124122.pdf

42. Ross S, Walker A, MacLeod MJ. Patient compliance in hypertension: role of illness perceptions and treatment beliefs. J Hum Hypertens 2004; 18: 607-613.

43. Kim TJ, von dem Knesebeck O. Is an insecure job better for health than having no job at all? A systematic review of studies investigating the health-related risks of both job insecurity and unemployment. BMC Public Health 2015; 15: 985.

44. Juszczak D, Talarowska M, Kowalewski M, Filewski A. Charakterystyka zaburzeń lękowych - występowanie w stwardnieniu rozsianym, możliwości leczenia oraz wpływ na proces rehabilitacji [Characteristics of anxiety disorders - prevalence among patients with multiple sclerosis, treatment optuons and effect on rehabilitation]. Polski Merkuriusz Lekarski 2009; 27: 162.

45. Charmaz K. Loss of self: a fundamental form of suffering in the chronically ill. Sociol Health Illn 1983; 5: 168-195.

46. Przychodzka E, Lorencowicz R, Turowski K, Bednarz E. Funkcjonowanie społeczne i zawodowe pacjentów z SM [Social and vocational functioning of patients with multiple sclerosis]. Zdrowie i Dobrostan 2013; 4: 213233.

47. Rzepa T. Piętno choroby w kontekście stwardnienia rozsianego [The stigma of illness and multiple sclerosis]. W: Potemkowski A (ed.). Psychologiczne aspekty stwardnienia rozsianego [Psychological aspects of multiple sclerosis]. Poznań: Termedia Wydawnictwo Medyczne; 2010, p. 15-28.

48. Goffman E. Piętno. Rozważania o zranionej tożsamości. Gdańsk: Gdańskie Wydawnictwo Psychologiczne; 2005.

49. Prusiński A. Neurologia kliniczna [Clinical neurology]. Warszawa: Wydawnictwo Lekarskie PZWL; 2005.

50. Jopson NM, Moss-Morris R. The role of illness severity and illness representations in adjusting to multiple sclerosis. J Psychosom Res 2003; 54: 503-511. 
Self-perception of illness among patients with relapsing-remitting multiple sclerosis (RRMS) - preliminary report

Percepcja własnej choroby przez osoby z rzutowo-remisyjna postacia stwardnienia rozsianego (SMRR) - doniesienie wstępne

51. Dennison L, Moss-Morris R, Chalder T. A review of psychological correlates of adjustment in patients with multiple sclerosis. Clin Psychol Rev 2009; 29: 141-153.

52. Telford K, Kralik D, Koch T. Acceptance and denial: implications for people adapting to chronic illness: literature review. J Adv Nursing 2006; 55: 457-464.

53. A-Tjak JG, Davis ML, Morina N, Powers MB, Smits JA, Emmelkamp PM. A meta-analysis of the efficacy of acceptance and commitment therapy for clinically relevant mental and physical health problems. Psychother Psychosom 2015; 84: 30-36. 